\title{
Masyarakat Konsumsi dan Simulasi Pengunjung Coffee Shop Janji Jiwa di Kota Padang
}

M. Abdi Azzara ${ }^{1}$, Azwar Azwar ${ }^{2}$, Elfitra Elfitra ${ }^{3}$

1,2,3 Universitas Andalas

Email: abdi.azzara.muhammad@gmail.com,nadzelazwar@gmail.com, elbaiko69@gmail.com

\begin{abstract}
Abstrak
Janji Jiwa merupakan coffee shop paling popular, dan Sumatera Barat sebagai salah satu Provinsi dengan jumlah peminum serta kunjungan coffee shop tertinggi secara nasional. Sesuai dengan tujuan penelitian maka tulisan ini akan membahas mengenai motif-motif konsumsi serta konstruksi gaya hidup konsumerisme di kalangan pengunjung coffee shop Janji Jiwa di Kota Padang. Untuk menganalisis data yang terkumpul peneliti menggunakan perspektif Jean P Baudrillard terkait masyarakat konsumsi. Metode yang digunakan pendekatan kualitatif, dengan tipe penelitian studi kasus (single case study). Pemilihan informan dilakukan secara purposive sampling dengan jumlah informan 9 orang yang terdiri dari informan pelaku dan informan pengamat. Untuk analisis data, peneliti menggunakan analisis interaktif Miles dan Huberman, untuk menjamin validitas dan reliabilitas data maka peneliti melakukan uji triangulasi data. Hasil dari penelitian menunjukan adanya pergeseran motif konsumsi dimana konsumsi yang terjadi bukan didasari pada motif-motif pemenuhan kebutuhan biologis, melainkan sebagai bentuk aktualisasi diri dalam rangka signifikansi dan klasifikasi sosial. Terbentuknya pandangan imajiner dan konstruksi gaya hidup konsumerisme tidak terlepas dari hukum kausalitas yang kompleks dan beragam, ditinjau dari aspek nilai tanda, logika sosial konsumsi, ruang sosial, dan media tontonan. Keseluruhan aspek tersebut sarat akan simulasi dan simulasi tersebut diproduksi ulang baik dalam bentuk abstrak maupun konkrit. Fakta ini merupakan bukti irasionalitas masyarakat kontemporer kedalam bentuk perilaku konsumtif.
\end{abstract}

Kata Kunci: Coffee Shop, Kebutuhan Palsu, Konsumerisme, Simulasi, Tanda

\begin{abstract}
Janji Jiwa is the most popular coffee shop, and West Sumatra is one of the provinces with the highest number of drinkers and coffee shop visits nationally. In accordance with the objectives of the study, this paper will discuss consumption motives and the construction of a consumerist lifestyle among visitors to the Janji Jiwa coffee shop in Padang City. To analyze the data collected, the researcher uses the perspective of Jean P Baudrillard regarding consumption society. The method used is a qualitative approach, with the type of case study research (single case study). The selection of informants was carried out by purposive sampling with a total of 9 informants consisting of informants of actors and informants of observers. For data analysis, the study used Miles and Huberman interactive analysis, to ensure the validity and reliability of the data, the researchers conducted a data triangulation test. The results of the study indicate a shift in consumption motives where consumption is not based on the motives for fulfilling biological needs, but as a form of selfactualization in the context of social significance and classification. The formation of an imaginary view and the construction of a consumerist lifestyle cannot be separated from the law of causality which is complex and diverse, in terms of sign value, social logic of consumption, social space, and spectacle media. All these aspects are full of simulations and the simulations are reproduced in both abstract and concrete forms. This fact is evidence of the irrationality of contemporary society in the form of consumptive behavior.
\end{abstract}

Keywords: Consumerism, Coffee Shop, Fake need, Signs, Simulation 
M. Abdi Azzarra, Azwar Azwar, Elfitra Elfitra

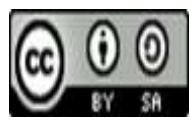

Received: October 21, 2021

Revised: December 29, 2021 Available Online: December 31, 2021

\section{Pendahuluan}

Dalam perkembangannya, era modern ternyata tidak hanya menawarkan pengaruh positif bagi kehidupan masyarakat. Namun juga memberikan sisi-sisi gelap yang siap menghancurkan kehidupan manusia itu sendiri (Dewi, 2013). Belakangan kemunculan coffee shop di Indonesia beserta konsep modern yang mereka tawarkan menjadi daya tarik bagi para pengunjung, modern dalam konteks ini selalu mencirikan kesenangan sehari-hari. Konsumsi komoditas modern pada dasarnya berperan sebagai pembeda seseorang dari masyarakat tradisional (Heryanto, 2015). Dengan demikian mengkonsumsi kopi di coffee shop merupakan sebuah upaya seseorang untuk keluar dari pola-pola tradisional.

Berdasarkan data dari International Coffee Organization, jumlah konsumsi kopi di Indonesia terus meningkat. Data ini dibuktikan dengan menjamurnya coffee shop dan kegiatan promosi seputar kopi yang biasa ditemukan di acara tertentu. Indonesia termasuk dalam lima produsen kopi di dunia. Pada periode Oktober 2018 - September 2019 konsumsi pangsa konsumsi kopi Indonesia di antara negara-negara produsen di kawasan Asia dan Oseana merupakan yang tertinggi, yaitu 4,8 juta kantong kopi/tahun (Laksmi, 2020). Angka ini tentunya memberikan tanda bahwa mengkonsumsi kopi adalah bagian dari kehidupan masyarakat Indonesia.

Menurut Thorstein Veblen situasi post-industrialis memunculkan kelompok masyarakat baru yang menjadi cikal bakal budaya konsumerisme, yaitu kelompok kelas menengah baru (Damsar \& Indrayani, 2009). Menurut BPS (Badan Pusat Statistik), kenaikan penduduk kelas menengah di Indonesia mencapai delapan sampai sembilan juta penduduk pertahun (Stellarosa, 2020). Kemunculan kelas menengah baru khususnya di Indonesia memberikan dampak terhadap daya konsumsi masyarakat. Untuk di Sumatera Barat, ditinjau dari PDRB semenjak tahun 2010 hingga saat ini selalu mengalami kenaikan, kesimpulannya budaya konsumerisme dilatarbelakangi oleh daya konsumsi dari masyarakat itu sendiri.

Daya konsumsi masyarakat terus meningkat, tidak hanya dalam hal pemenuhan kebutuhan-kebutuhan pokok, tetapi juga mencakup kebutuhan simbolik. Minum kopi sudah menjadi gaya hidup bagi sebagian masyarakat Indonesia. Menurut survey dari HonestDocs rata-rata perempuan Indonesia minum segelas kopi perhari $(64,4 \%)$, sementara mayoritas lakilaki bisa menghabiskan dua atau tiga gelas kopi dalam sehari (21\%). Sisanya bisa minum kopi 4 sampai 5 atau bahkan 11 gelas per harinya (Yayuk, 2019). Untuk Provinsi dengan jumlah konsumsi dan kunjungan coffee shop tertinggi salah satunya didominasi oleh Provinsi Sumatera Barat dengan angka 57\% sebanding dengan Provinsi DKI Jakarta dengan kepadatan penduduk yang lebih tinggi (Yayuk, 2019). Observasi awal Kota Padang memiliki berbagai macam merek coffee shop, baik itu coffee shop lokal maupun nasional. Untuk membatasi objek penelitian maka peneliti berfokus pada salah satu coffee shop ternama di Indonesia yaitu Kopi Janji Jiwa.

Kopi Janji Jiwa berhasil meraih penghargaan bergengsi Top Brand dua kali berturutturut, di tahun 2020 Janji Jiwa memperoleh skor TBI sebesar 29,8\% dibawah Kopi Kenangan dengan skor 39,9\% namun pada tahun 2021 Janji Jiwa berhasil menduduki posisi teratas Top Brand dengan skor 39,5\% dalam segmentasi kategori kedai kopi terbaik (Lestari, 2020). Top 
Brand adalah sebagai bentuk penghargaan tertinggi di berbagai jenis produk industri yang meraih posisi puncak.

Menurut hasil survey yang dilakukan Janji Jiwa menjadi pangsa puncak pikiran masyarakat secara keseluruhan, dan menjadi pangsa teratas sekaligus pangsa komitmen teratas. Artinya belakangan ini, orang-orang banyak membicarakan tentang Janji Jiwa dan Janji Jiwa telah menjadi brand coffee shop terpopuler hingga sukses membangun representasi masyarakat terhadap Janji Jiwa sebagai bagian dari simbol kemapanan dan gaya hidup konsumsi masyarakat kontemporer. Permasalahan muncul ketika kemudahan dan penawaran mereka terkapitalisasi kedalam bentuk strategi marketing, sehingga memunculkan pergeseran perilaku konsumsi yang berakibat timbulnya perilaku-perilaku konsumtif. Janji Jiwa secara tidak langsung telah mengkampanyekan kepada sekelompok masyarakat tertentu, bahwa dengan mengkonsumsi kopi di coffee shop mereka sudah menjadi simbol kemewahan, eksklusifitas, serta penanda kelas sosial.

Masyarakat di Kota Padang mayoritas adalah orang Minangkabau, dilihat dari sejarahnya minuman kopi memang telah menjadi bagian dari kehidupan mereka. Seiring perkembangan zaman, minuman kopi tidak lagi dianggap sesederhana minuman-minuman yang biasa ditemukan pada lapau atau warung kopi dalam bahasa Indonesia (Yandri, 2017). Kopi sudah menjadi minuman eksklusif dan bahkan profesi penyeduh kopi membutuhkan profesionalisme tinggi, untuk itu hari ini minuman kopi pantas dihargai lebih mahal berkali-kali lipat. Faktanya meskipun hari ini minuman kopi tergolong mahal tetap saja semua kalangan ada untuk mencicipinya, terlepas apakah mereka memang benar-benar menjadi seorang penikmat kopi atau hanya sekedar membeli gaya hidup. Dilihat dari persebaran usia, secara empiris dapat disimpulkan mereka yang terlibat dalam aktivitas konsumsi minuman kopi Janji Jiwa sebagian besar adalah kelompok-kelompok remaja perkotaan baik itu laki-laki atau perempuan tanpa pertimbangan apakah mereka bagian dari kelompok mapan atau tidak, karena masyarakat hari ini cenderung terbiasa menilai keimanan seseorang bukan dari tingkat pendapatan akan tetapi melihat apa-apa yang dikonsumsi, sehingga siapapun bisa menjadi bagian dari kelompok sosial manapun.

Menurut Susilo (2015) perkembangan pola konsumsi dalam masyarakat menciptakan klasifikasi terhadap makanan yang menandai peradaban manusia masa kini. Dengan mengkonsumsi kopi di coffee shop dapat menjadi klasifikasi dan penentu atas identitas masyarakat masa kini. Gagasan ini kemudian ditularkan lewat desain warung kopi. Harga yang relatif mahal, cara berbusana para pelanggan, hingga penggunaan bahasa konsumen yang disebut sebagai gimmick (Susilo, 2015). Rasionalitas dalam masyarakat modern berusaha mengarahkan pilihan masyarakat kepada apa yang diinginkan kelompok industrialis. Untuk itu penelitian ini bertujuan untuk menjelaskan bagaimana perilaku konsumtif terbentuk dan muncul pada kalangan pengunjung coffee shop Janji Jiwa sebagai produsen coffee shop terbesar di Indonesia.

Penelitian serupa terkait dengan budaya konsumerisme pengunjung coffee shop telah dilakukan oleh beberapa peneliti sebelumnya. Ahmad Sayyidul Haq Ar Rabbani Lubis dalam penelitiannya mencoba menjelaskan terbentuknya perilaku konsumtif di kalangan milenial pengunjung Starbuck Coffee di Kota Medan (Lubis, 2020). Selain itu penelitian dari Molekandella Boer Kheyene, yang menjelaskan Starbuck Coffee sebagai representasi gaya hidup konsumerisme barat yang dikonstruksikan melalui hegemoni kapitalisme (Kheyene, 2013). Kemudian Novia Theresia Br. Sembiring, dalam penelitiannya di Cafe Holywings Kota Medan menunjukan bahwa tampilan western berdampak terhadap logika konsumsi sehingga aktivitas konsumsi yang terjadi sarat akan simbol-simbol modernitas (Sembiring, 2020). Meskipun penelitian sebelumnya telah membahas terkait budaya konsumerisme dalam arena 
coffee shop, namun menurut peneliti perkembangan varian-varian dan merek coffee shop selalu mengalami perkembangan. Jika sebelumnya Starbuck dijadikan acuan dalam analisis budaya konsumerisme penikmat coffee shop, maka hari ini Janji Jiwa menjadi merek yang lebih menarik untuk dikaji. Dengan begitu penelitian ini memiliki kebaruan yang belum pernah dibahas oleh penelitian-penelitian sebelumnya.

Penelitian ini juga semakin menarik karena temuan-temuan dianalisis melalui perspektif Jean P Baudrillard terkait masyarakat konsumsi serta analisis dunia simulasi melalui hermeneutika Saussure. Kemudian dalam penelitian ini juga banyak meminjam pokok-pokok pikiran dari seorang filsuf kontemporer yaitu Herbert Marcuse. Maka dari itu, merumuskan pertanyaan penelitian sebagai berikut: Bagaimana analisis perilaku konsumsi yang terjadi pada kalangan pengunjung coffee shop Janji Jiwa melalui perspektif Jean P Baudrillard? Diharapkan melalui penelitian ini pembaca dapat memahami motif-motif konsumsi serta konstruksi gaya hidup konsumerisme pengunjung coffee shop Janji Jiwa terutama di Kota Padang dalam perspektif Jean P Baudrillard.

\section{Metode Penelitian}

Penelitian ini menggunakan pendekatan kualitatif, sedangkan tipe penelitian yang digunakan adalah studi kasus (single case study). Metode ini dianggap mampu untuk mengungkap motif-motif serta konstruksi gaya hidup konsumerisme kalangan pengunjung coffee shop Janji Jiwa di Kota Padang. Teknik pengumpulan data yang digunakan meliputi observasi, wawancara dan dokumentasi. Selama proses pengumpulan data peneliti mencoba untuk mengamati dan sesekali terlibat sebagai pengunjung di coffee shop Janji Jiwa. Peneliti mencoba memahami berbagai aktivitas pengunjung serta simbol-simbol yang terdapat baik pada diri pengunjung itu sendiri atau dari penampilan Janji Jiwa dilihat dari arsitektur dan ornamen yang mereka gunakan. Untuk memahami lebih lanjut peneliti melakukan proses wawancara dengan informan yang sudah ditentukan (purposive sampling) dengan jumlah informan 9 orang. Alasan peneliti menggunakan teknik purposive sampling karena aktivitas konsumsi pengunjung Kopi Janji Jiwa tidak terlepas dari fakta-fakta berkaitan dengan orangorang di luar dari pengunjung itu sendiri, seperti pihak Janji Jiwa atau profesional barista yang lebih memahami kopi baik secara filosofi maupun historis. Sumber-sumber lainnya seperti dokumentasi juga sangat membantu dalam menyusun penelitian ini. Untuk analisis data, penelitian menggunakan analisis interaktif Miles dan Huberman, untuk menjamin validitas dan reliabilitas data maka peneliti melakukan uji triangulasi data. Penelitian ini dilakukan selama 5 bulan terhitung semenjak bulan Maret 2021 hingga Agustus 2021.

\section{Hasil dan Pembahasan}

\section{Motif Konsumsi Pengunjung Coffee shop Janji Jiwa}

Masyarakat hari ini, atau individu-individu yang terlibat dalam aktivitas konsumsi di coffee shop Janji Jiwa pada dasarnya bukan sebagai penikmat kopi. Sebagian besar informan menjelaskan bahwa motif kunjungannya didasari ketertarikan atas tempat yang dianggap menarik. Hasil observasi menunjukan, bahkan tidak semua dari konsumen yang datang memesan kopi, bahkan mereka lebih memilih minuman non coffee. Selain itu beberapa konsumen tampak tidak menghabiskan minumannya, asumsinya ada hal yang lebih penting diluar nilai fungsi kopi itu sendiri, dalam kasus ini ada hasrat lebih dari individu yang memaksa untuk datang dan terlibat menjadi pelanggan di coffee shop Janji Jiwa. Seperti yang dijelaskan oleh salah seorang informan pengamat yang bernama AB Sarca Putra yang menyatakan jika memang mereka membutuhkan kopi guna manfaat biologis maka mereka akan lebih memilih 
kopi tubruk. Informan pelaku juga mengkonfirmasi hal tersebut, salah satunya infroman yang bernama Nurul Aficha menyatakan, bahwa:

"Niat nya kan mau nongkrong, happy-happy sama teman-teman kadang lupa juga
minumannya nggak abis palingan kopi susu, kopi milo, kopi coklat. Kalau yang
kayak-kayak Fitnam Drip, five sixty atau apalah saya nggak suka Haha sebenarnya
bukan sih, kan tujuan nya itu tadi mau nongkrong." (Wawancara 21 Juni 2021).

Max Weber dalam Economy and Society, menjelaskan bahwa tindakan ekonomi adalah sebuah tindakan sosial (Damsar \& Indrayani, 2009). Untuk itu peneliti juga mengelompokan beberapa informasi mengenai aktivitas pengunjung coffee shop Janji Jiwa sebagai sarana kebutuhan sosial. Setidaknya ada 67 kali kata "nongkrong" ditemukan dalam transkrip wawancara. Untuk itu Janji Jiwa hanyalah sebagai tempat dirasa mampu menjelaskan aktivitasaktivitas para pengunjungnya, salah satu aktivitas utamanya adalah "nongkrong" karena menurut penelitian sebelumnya dijelaskan bahwa persepsi anak-anak muda terhadap maraknya kafe kerap diasosiasikan menjadi bagian dari gaya hidup, sehingga aktivitas nongkrong di coffee shop merupakan sebagai bentuk distingsi terhadap kelompok lainnya yang tidak memilih coffee shop sebagai pilihan "nongkrong" mereka. Terkait konsep ini nantinya akan dibahas lebih mendalam pada bagian: Ruang Sosial Pengunjung Coffee Shop Janji Jiwa.

Motif lainnya yaitu membeli dengan alasan kemasan menarik. Era Globalisasi saat sekarang ini mempertajam persaingan bisnis. Untuk itu kemasan menjadi sebuah "Perangkap Emosional" yang ampuh menarik perhatian konsumen, kemasan memiliki daya tarik dan perhatian bagi para pembeli atau konsumen. Kemasan dapat digunakan sebagai sarana dalam meningkatkan citra, merangsang persepsi dan alat dalam menarik minat membeli (Willy \& Nurjanah, 2019). Hasil observasi menunjukan, perilaku informan cenderung menyukai kemasan cup minuman Janji Jiwa, secara konkret dapat dipahami melalui aktivitas memfoto cup minuman. Dari pengamatan peneliti memang kemasan minuman Janji Jiwa memiliki keunikan tersendiri, yaitu dalam bentuk quote. Menurut penelusuran peneliti, dibeberapa coffee shop lainnya quote atau tulisan di kemasan memang bisa kita temui, akan tetapi dari penelusuran lebih mendalam ternyata Janji Jiwa adalah sebagai pelopor cup minuman yang diberi tulisan dalam bentuk quote. Hasil wawancara juga menunjukan ungkapan ketertarikan mereka dan menjadi suatu kebanggan tersendiri juga memposting foto cup minuman Janji Jiwa pada medsos masing-masing sebagai bukti mereka juga pernah menjadi bagian dari konsumen Janji Jiwa.

Seperti kutipan wawancara kami bersama informan yang bernama Allan Kurniawan yang menjelaskan ketertarikan terhadap Janji Jiwa dimulai dari hal-hal yang bersifat visual terutama kemasan.

"Ya Janji Jiwa ini baik dari kemasan atau penampilan Kedai kopinya tergolong menarik, Kalau beli gofood kan nampak tuh gambar-gambarnya, nah kalau menurut saya penampilan cupnya menarik" (Wawancara 10 Juli 2021).

Senada dengan apa yang dijelaskan oleh Fadhila Octari, bahwa:

"Kalau buka menu di Gofood lucu-lucu gitu bang menunya, kemasannya imut bagus kalau difoto ada tulisan-tulisan gitu kayak kopi dari hati, macam macam, indie bangetlah" (Wawancara 26 Juni 2021).

Motif lainnya yaitu membeli karena potongan harga yang diberikan. Dari observasi peneliti, selama pandemi terlebih diterapkannya PPKM di wilayah Kota Padang menyebabkan coffee shop Janji Jiwa tidak seramai hari-hari biasa, akan tetapi menurut keterangan Piter selaku 
manager operasional Janji Jiwa, tidak ada perubahan untuk penjualan. Hasil wawancara membuktikan bahwa ketertarikan untuk membeli produk di Janji Jiwa salah satunya dipengaruhi oleh potongan-potongan harga, terutama pada masa pandemi. Orang-orang dianjurkan untuk membeli kebutuhan melalui marketplace. Janji Jiwa tentu tidak menyianyiakan kesempatan tersebut, mereka kemudian memberikan berbagai macam diskon-diskon untuk produknya jika membeli melalui Gofood atau istilah bagi mereka Grab and Go. Hasil wawancara menunjukan sebagian besar informan terindikasi melakukan pembelian secara impulsif karena pertimbangan potongan harga atau produk ditentukan oleh visualisasi seberapa menarik foto produk tersebut.

Bagi sebagian kecil informan lainnya, menjelaskan bahwa potongan harga tidak menjadi satu-satunya alasan konsumsi mereka, informan-informan menjelaskan menyukai menu di Janji Jiwa karena variatif dan kekinian. Seperti apa yang dijelaskan oleh informan yang bernama Siska Pratama, bahwa

“Tapi saya suka minumannya. Minusnya saya kurang eksplor menu-menu coffee palingan menu lain-lain gitu. Kalau untuk pribadi saya sekarang karena kerja pagi kalau minum kopi nongkrong malam jadi susah tidur jadi saya menghindari untuk begadang. Kalau dulu hajar aja" (Wawancara 21 Juni 2021).

Senada dengan apa yang dijelaskan Reynaldi, bahwa:

"Minumannya iya juga sih, tapi Janji Jiwa punya daya tarik tersendiri kalau soal kenyamanan. Ya bedalah, kalau disini kan kopi kekinian. Kalau pagi bangun tidur biasa kopi sachet aja, tapi kalau mau nongkrong ya bukan kopi begituan." (Wawancara 15 Juni 2021).

Sebenarnya tidak ada yang tidak konsumtif jika berbicara mengenai fenomena konsumsi pengunjung Coffee shop Janji Jiwa. Meskipun memang betul-betul menyukai minumannya akan tetapi tetap saja, yang dilakukan adalah sebagai bentuk tindakan konsumtif, karena kopi sudah melampaui nilai fungsinya. Dari sini kita bisa memahami sebagian besar informan mengkonsumsi produk Janji Jiwa karena fungsi afektif atas dasar keinginan atau rasanya yang "enak".

Motif konsumsi selanjutnya sekaligus penutup bagian ini yaitu aktivitas berfoto sebagai motif konsumsi. Dari observasi peneliti, memang sebahagian besar aktivitas berfoto di coffee shop menjadi lumrah, lumrah selagi itu tidak mengganggu konsumen lainnya. Ruangan serta pemandangan yang estetik tentu menimbulkan pergeseran orientasi konsumsi. Seperti apa yang dijelaskan oleh salah satu informan yang bernama Nurul Aficha

"Ya udah emang kayak gitu zamannya sekarang ya kan sosial media sedang berkembang banget sedang marak-maraknya jadi orang emang apa tuh namanya pasti pengen eksis lagi itu istilahnya benar-benar pengen apa ya high profile kayak gitu. Jadi mereka ya biasa aja sih wajar-wajar aja. Nggak mau ketinggalan zaman jugalah, orang post ke Janji Jiwa masak kita enggak" (Wawancara 21 Juni 2021).

Dari kutipan wawancara, dapat diketahui bahwa Janji Jiwa punya daya tarik tersendiri bagi pengunjung untuk berebut spot foto Instagramable. Kebiasaan berfoto memang sudah menjadi rutinitas wajar bagi kalangan pengunjung coffee shop. Serupa dengan hasil penelitian Salendra yang berjudul Coffee shop as a Media for Self-Actualization Today's Youth. Penelitian ini mencoba menjelaskan bahwa sosial media sebagai penunjang aktualisasi diri remaja saat ini melalui budaya nongkrong (Salendra, 2014). 
Menurut Ritzer dalam buku Jean P Baudrillard individu secara sadar berupaya untuk membedakan dirinya dari orang lain, namun sistem pembeda itulah yang menyebabkan individu mirip (Baudrillard, 2011). Aktivitas berfoto dan upload foto di sosial media pada dasarnya bertujuan untuk membedakan dirinya atas orang lain, akan tetapi malah terlihat sama saja ketika mereka hanya memfokuskan diri terhadap konsumsi tanpa mempertimbangan substansinya. Baudrillard dalam sudut pandangnya menjelaskan bahwa masyarakat hari ini dikuasai oleh prinsip-prinsip teknologi, salah satunya gadget (Baudrillard, 2011). Bermunculannya berbagai platform media sosial sebagai bentuk kuasa dari prinsip teknologi maka muncul pula kebiasaan baru ditengah masyarakat hari ini. Media sosial telah menjadi perantara dalam pembentukan tanda, atau yang disebut Baudrillard sebagai diferensiasi. Konsumsi sebagai alat penentu status sosial adalah realitas kepalsuan, untuk itu stratifikasi yang terbentuk karena sistem tanda tersebut hanya layak dikatakan sebagai diferensiasi.

\section{Konstruksi Gaya Hidup Konsumerisme di Kalangan Pengunjung Coffee shop Janji Jiwa di Kota Padang}

Menurut Baudrillard perilaku konsumtif yang tumbuh didalam kehidupan sosial masyarakat hari ini pada dasarnya berhubungan dengan hukum sebab akibat yang sangat kompleks. Perilaku konsumtif dikonstruksikan melalui beberapa abstraksi yaitu: nilai tanda, ruang sosial, media tontonan, dan logika konsumsi sosial (Lubis, 2020). Melalui wawancara dan dokumentasi, peneliti sudah mengumpulkan beberapa fakta-fakta terkait bentuk stimulus yang diberikan Janji Jiwa terhadap konsumennya sehingga memunculkan nilai-nilai tanda terhadap suatu objek material. Dari hasil penemuan penelitian pada dasarnya ada tiga aspek penting yang mengalami pergeseran nilai fungsi kemudian menjadi nilai tanda, lebih jelasnya dapat dilihat melalui tabel berikut:

Tabel 1. Aspek penting yang mengalami pergeseran nilai fungsi menjadi nilai tanda

\begin{tabular}{|c|c|c|c|c|c|}
\hline No & Aspek & Nilai Guna & $\begin{array}{c}\text { Nilai yang } \\
\text { dipertukarkan }\end{array}$ & $\begin{array}{c}\text { Pertukaran } \\
\text { Simbolik }\end{array}$ & Nilai Tanda \\
\hline 1 & $\begin{array}{l}\text { Simbol Ke- } \\
\text { Indonesiaan }\end{array}$ & $\begin{array}{l}\text { Identitas } \\
\text { Coffee Shop }\end{array}$ & Sakral & $\begin{array}{l}\text { Slogan, Batik, } \\
\text { dan Oranamen }\end{array}$ & $\begin{array}{l}\text { Nasionalisme } \\
\text { (Diferensiasi) }\end{array}$ \\
\hline 2 & $\begin{array}{l}\text { Aksesibilitas } \\
\text { (Cepat Saji } \\
\text { dan Self } \\
\text { Service, } \\
\text { Pembayaran } \\
\text { Non Tunai, } \\
\text { Konsep Grab } \\
\text { and Go) }\end{array}$ & Efisiensi & $\begin{array}{l}\text { Ekonomis dan } \\
\text { Kemudahan }\end{array}$ & $\begin{array}{l}\text { Cepat Saji dan } \\
\text { Self Service, } \\
\text { Pembayaran } \\
\text { Non Tunai, } \\
\text { Konsep Grab } \\
\text { and Go }\end{array}$ & $\begin{array}{l}\text { Eksklusif } \\
\text { (Diferensiasi) }\end{array}$ \\
\hline 3 & Desain Interior & Kenyamanan & Estetika & $\begin{array}{l}\text { Kursi, Meja, } \\
\text { Ornamen, } \\
\text { Bangunan, dan } \\
\text { Lokasi }\end{array}$ & $\begin{array}{l}\text { Eksklusif } \\
\text { (Diferensiasi) }\end{array}$ \\
\hline
\end{tabular}

Sumber: Disusun oleh penulis berdasarkan hasil penelitian dan analisis data

Dari tabel di atas kita bisa memahami adapun nilai tanda yang terdapat pertama yaitu simbol-simbol ke-Indonesiaan yang menjadi ornamen di coffee shop Janji Jiwa. Menurut hasil wawancara bersama informan Janji Jiwa menjadi tidak asing lagi bagi para konsumen, bahkan 
dari hasil wawancara menunjukan adanya distingsi yang terjadi, dengan mengunjungi coffee shop merek nasional maka sudah menjadi penanda seseorang memiliki jiwa nasionalisme, untuk itu nasionalisme dibentuk dan dikonstruksikan dalam sistem tanda, dan lebih parahnya kapitalisme seolah-olah menunggangi unsur-unsur nasionalisme dalam membangun persepsi masyarakat terhadap suatu komoditas. Nasionalisme yang ditunggangi kapitalis merupakan bentuk permainan budaya masa sebagai salah satu sumber utama suatu moralitas pengganti dan palsu (Strinati, 2021). Begitu juga dengan nilai tanda lainya, aksesibilitas dalam bentuk pelayanan membentuk pemahaman baru bagi pengunjung terhadap pola pelayanan yang dianggap ideal sekaligus modern. Ritzer dalam bukunya juga menjelaskan bahwa mengkonsumsi makanan cepat saji menjadi sebuah "tanda" yang berkesesuaian dengan gaya hidup modern (Ritzer, 2014). Sama halnya dengan desain interior di coffee shop Janji Jiwa yang kemudian dikonstruksikan sebagai penanda prestise.

Rekayasa simbol dan tanda adalah bentuk rekayasa konsumerisme melalui gaya hidup. Semua komoditi punya tanda dan petandanya tersendiri, menurut Baudrillard perubahan status komoditi masa kini disebabkan oleh struktur tanda itu sendiri, tanda merupakan jantung dari komoditi masa kini (Aziz, 2001). Mustahil bermunculan berbagai bentuk kebutuhan palsu tanpa nilai tanda dan simbol dalam sebuah komoditas. Terkadang dalam sistem tanda orangorang cenderung melampaui realitasnya dan seolah-olah mereka sudah merasakan menjadi bagian dari tanda itu sendiri tanpa menyadari kenyataan yang sebenarnya. Maka Baudrillard menyatakan masyarakat hari ini hidup didalam dunia simulasi tanda (Piliang, 2011).

Kemudian terkait dengan Media dan Tontonan, Keseluruhan informan yang diwawancarai pada dasarnya memiliki akun sosial media masing-masing, baik itu Instagram, Facebook, Twitter, Tiktok, dll. Sebagian besar informan menjelaskan bawa ketertarikan dengan Janji Jiwa hingga menjadi kebiasaan konsumsi di mulai dari aktivitas di media sosial. Sosial media dengan berbagai macam fitur menarik seperti feed, explore, snapgram, caption dan hastag membantu menyebarluaskan informasi. Sebagian besar generasi muda $(65,3 \%)$ memanfaatkan Teknologi informasi sebatas untuk memenuhi kebutuhan personal terutama kebutuhan komunikasi dan hiburan yang lebih berorientasi ke gaya hidup konsumtif (Teguh et al., 2010). Pihak Janji Jiwa tidak menyangkal bahwa Media Massa sebagai wadah utama strategi marketing. Sebagai bukti dokumentasi kita bisa melihat beberapa contoh postingan new media sosial dari coffee shop Janji Jiwa:

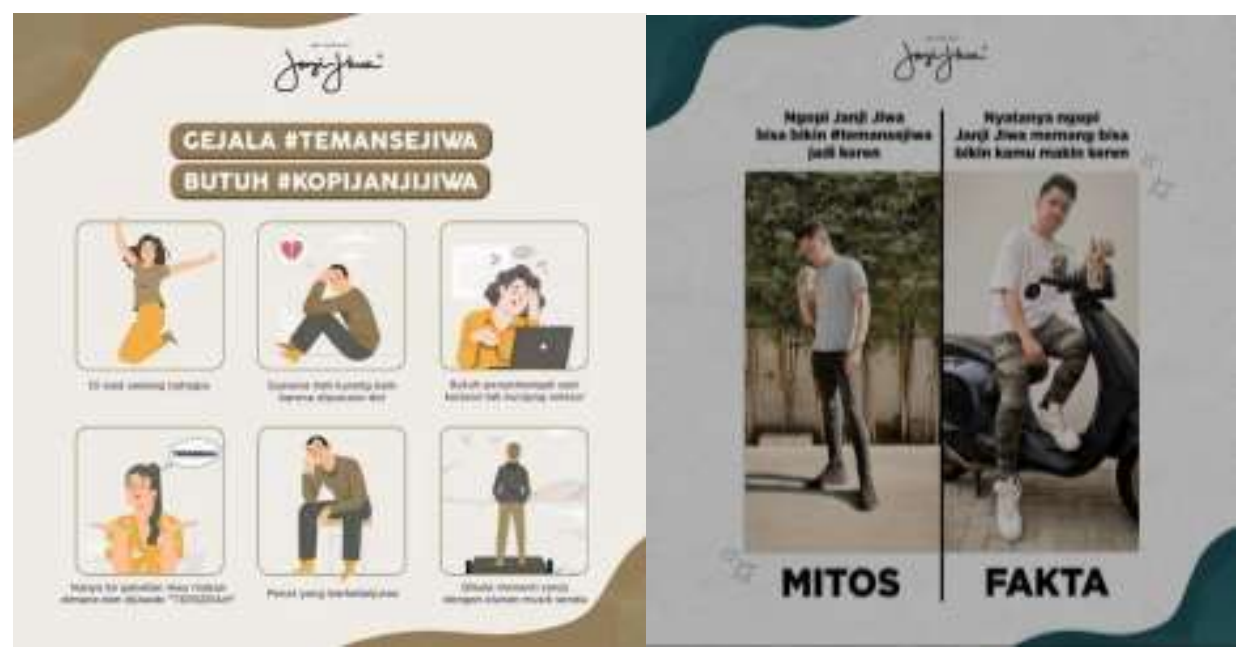

Gambar 1. Diambil dari salah satu new media sosial Janji Jiwa 
Pada dasarnya seluruh informan mengakui bahwa mereka mengenal brand Janji Jiwa dan terlibat dalam aktivitas konsumsi dimulai semenjak Janji Jiwa muncul di new media sosial. Mereka menawarkan berbagai kebutuhan-kebutuhan palsu dalam iklan dunia hiperealitas melalui simbol-simbol guna meningkatkan keinginan masyarakat untuk terus membeli (Hanif, 2011). Tidak hanya itu, media partner juga menjadi sarana Coffee shop Janji Jiwa dalam membentuk perilaku konsumsi. Janji Jiwa banyak melakukan kerjasama media partner baik itu dengan orang berpengaruh, lembaga, atau merek lainnya yang memiliki kepopuleran, dalam rangka mempromosikan brand dan produknya Janji Jiwa melakukan promosi digital dan berkolaborasi dengan merek-merek potensial. Seperti:

Tabel 2. Promosi digital dan kolaborasi produk Janji Jiwa

\begin{tabular}{ccc}
\hline No & Kerjasama & Keterangan \\
\hline 1 & Muhammad Aga & Peserta Kejuaraan Dunia Barista \\
\hline 2 & Gundala & Film pahlawan super Indonesia \\
\hline 3 & Kick Avenue & Marketplace sneakers Indonesia \\
\hline 4 & Lock\&Lock featuring & Perusahaan produk rumah tangga Korea dan seniman \\
jalanan Indonesia
\end{tabular}

Sumber: Disusun oleh penulis berdasarkan hasil penelitian dan analisis data Sekunder

Merujuk terhadap tabel tersebut, maka kita mampu memahami Janji Jiwa memang tidak sembarangan dalam membangun persepsi individu melalui media. Hubungan kerjasama yang dibangun Janji Jiwa memiliki keterkaitan terhadap "siapa yang hari itu menjadi pusat perhatian publik". Kunci suksesnya adalah dengan tidak melawan atau menaklukkan ombak secara frontal, tetapi mencari cara yang tepat untuk memanfaatkan energi ombak tersebut (Teguh et al., 2010)

Fakta lainnya berkaitan dengan ruang sosial, dari hasil wawancara membuktikan budaya nongkrong di coffee shop sudah menjadi bagian dari kehidupan masyarakat kontemporer. Sebelumnya secara tradisional masyarakat Kota Padang sudah terbiasa dengan aktivitas nongkrong terutama di lapau atau warung kopi dalam bahasa Indonesia namun akibat perkembangan zaman serta kemunculan berbagai produk budaya populer menyebabkan orientasi tertuju pada arena coffee shop, lapau telah kehilangan eksistensinya dan tergantikan oleh coffee shop. Teman sebaya juga menjadi agen pembentuk perilaku konsumtif, bukan hanya teman nyata, akan tetapi juga termasuk teman-teman yang ada di dunia maya. Sedikit banyaknya Janji Jiwa banyak terbantu oleh aktivitas aplot foto di sosmed yang dilakukan oleh

Jurnal Socius: Journal of Sociology Research and Education Vol. 8, No. 2, Th. 2021 
konsumennya. Secara tidak langsung mereka sudah bertindak sebagai agen sosialisasi konsumsi.

Terakhir sekaligus penutup bagian ini, menurut Baudrillard perilaku konsumerisme yang terjadi salah satunya dipengaruhi oleh logika sosial konsumsi. Logika atau cara berpikir seseorang merupakan titik tolak terbentuknya sebuah realitas sosial. Sama halnya seperti apa yang dijelaskan oleh Michel Foucault. Sejarah berisi fragmen-fragmen tertentu yang dipengaruhi oleh cara berpikir seseorang pada suatu masa yang disebut epistem (Fahruddin, 2020). Konsumsi telah menjadi sebuah proses signifikansi dan klasifikasi sosial. Seperti yang dijelaskan oleh salah seorang informan yang bernama Fadhila Octari, bahwa:

"Difilem-filem kan kita biasa liat tuh, kalau hidup orang sekarang di coffee shop. salah satunya Janji Jiwa. Kayaknya sih kalau mau status sosialnya dikira baik nah pergilah ke Janji Jiwa. Ya balik lagi sih kalau saya boleh jujur sebenarnya ini mau pamer sih kita pernah kesana, ngak mau kalah juga sama yang lain. Janji Jiwa itukan apa ya biasanya yang kesana orang-orang oke aja" (Wawancara 25 September 2021).

Berbeda dengan apa yang disampaikan informan lain yang bernama Reynaldi:

"Ini bukan masalah gaya hidup akan tetapi ini masalah kenyamanan saja bang, saya sudah nyaman disini biarpun harganya mahal tapi itu bukan menjadi penghambat kita untuk ke Janji Jiwa, kita juga tengok fasilitasnya bukan harganya, yang jelas ada kesenangan tersendiri yang memang sulit untuk dijelaskan ketika kami ke Janji Jiwa" (Wawancara 13 Juni 2021).

Dari observasi memang simbol-simbol material yang menunjukan taraf kebahagiaan dan signifikansi banyak ditemukan. Logika sosial konsumsi memaksa orang-orang untuk mencari wujud kebahagiaan melalui tanda, atau simbol yang kemudian diberi pemaknaan. Untuk membedakan dirinya dengan orang lain atau sebagai proses signifikansi yang menunjukan bahwa mereka adalah orang-orang yang bahagia dan sejahtera, maka ditunjukan oleh tempat yang memiliki fasilitas dengan taraf kapital simbolik yang tinggi (distingsi).

\section{Matinya Realitas Konsumsi dan Munculnya Kebutuhan Palsu}

Asumsinya jika memang kopi dianggap sebagai kebutuhan biologis maka kita tidak perlu pergi ke coffee shop. Hari ini sebagian besar konsumen penikmat coffee shop Janji Jiwa disimpulkan mengkonsumsi kopi bukan karena aspek manfaat secara biologis akan tetapi didasari oleh kepentingan emosional. Ini sebagai contoh realitas masyarakat satu dimensi, yang hidup dalam berbagai macam kebutuhan-kebutuhan palsu, salah satunya kebutuhan aktualisasi diri melalui kegiatan nongkrong di coffee shop. Kebutuhan palsu adalah semua yang ditanamkan kepada masing-masing individu demi kepentingan sosial tertentu dalam represinya; yaitu kebutuhan untuk melanggengkan kerja keras, sikap agresif, kesengsaraan, dan ketidakadilan (Gultom, 2020)

Adanya persepsi bahwa status sosial ditentukan oleh apa yang dikonsumsi membuat orang-orang untuk berpacu untuk mengkonsumsi segala bentuk komoditas (Damsar \& Indrayani, 2009). Kelimpah-ruahan masyarakat kemudian dimanfaatkan oleh industri untuk menciptakan kebutuhan-kebutuhan baru. Logika kapitalisme membangun berbagai kebutuhan, dari konstruksi cara berpikir orang terhadap gaya hidup. Aktivitas konsumsi di coffee shop Janji Jiwa pada dasarnya jauh dari makna kebutuhan itu sendiri. Konsumsi hanya bagian dari gaya hidup, status, citra, atau kehormatan, dari penelitian yang dilakukan bahkan beberapa narasumber mengakui mengorbankan kebutuhan-kebutuhan lainnya demi menjadi bagian dari 
pengunjung di coffee shop Janji Jiwa. Aspek yang paling menonjol adalah, munculnya persepsi dengan mengunjungi coffee shop Janji Jiwa maka kita sudah menjadi bagian dari kelompok Leisure Class

Kebutuhan palsu merupakan realitas simulasi dalam realitas pengunjung coffee shop Janji Jiwa. Simulasi yang terjadi, dimulai dari bentuk yang abstrak hingga menjadi konkrit, pada dasarnya kebutuhan palsu adalah kebutuhan-kebutuhan yang berada pada tataran abstrak, kemudian menjadi konkrit sehingga kebutuhan yang sebenar-benarnya tidak dibutuhkan tadi seolah-olah memang benar-benar menjadi kebutuhan. Kebutuhan Palsu tentu tidak terjadi dengan sendiri, sama halnya dengan apa yang dijelaskan Baudrillard bahwa konsumsi merupakan sebuah paksaan terhadap individu-individu, dengan begitu realitas konsumsi adalah realitas yang sengaja diciptakan (Baudrillard, 2011). Pergeseran nilai dan keganjilan dalam rasionalitas masyarakat hari ini memaksakan pola-pola lama untuk ditinggalkan. Perlahanlahan kebutuhan kan minuman kopi menjadi meta konsumsi. Pada kenyataannya kegiatan ini hanya sebagai bentuk menciptakan realitas kebutuhan palsu, maka tidak diragukan lagi bahwa realitas konsumsi kopi terutama di Coffee shop Janji Jiwa hanyalah sebagai bagian dari perilaku konsumtif.

\section{Media Mensimulasikan Kebutuhan Palsu}

New media sosial dalam kehidupan berperan penting dalam membangun kebutuhankebutuhan. Arus informasi media bersifat linear, dari redaksi ke audiens. Model pesan yang bersifat top down menjadi peluang bagi para pengusaha untuk mengarahkan isi media kepada apa yang seharusnya mereka konsumsi. Akibatnya media tidak lagi menjadi ruang publik yang bebas dari intervensi berbagai kepentingan (Dwiana, 2015). Coffee shop Janji Jiwa tanpa disadari ikut terlibat dalam pembentukan budaya konsumerisme, buktinya dapat kita lihat melalui gencarnya penggunaan media massa. Janji Jiwa ikut membantu terbentuknya kebiasaan nongkrong sebagai budaya populer terutama bagi masyarakat Indonesia secara menyeluruh.

Media mensimulasikan kebutuhan palsu tidak terlepas dari konsep hiperrealitas, seperti cuplikan gambar-gambar dari beberapa postingan di media sosial Janji Jiwa. Mereka mencoba menampilkan visualisasi idealnya remaja perkotaan seperti apa, tentu dengan nongkrong, mengetahui menu-menu di Janji Jiwa, mendengarkan musik di Janji Jiwa dikatakan sebagai identitas remaja perkotaan. Secara tidak langsung para pengunjung Coffee shop Janji Jiwa juga ikut dalam situasi hiperealitas. Realitas kita yang asli telah runtuh karena telah diambil oleh rekayasa virtual, dalam hal ini new media sosial berperan besar dalam memalsukan identitas atau realitas individu yang sebenarnya (Karman, 2014). Melalui media sosial orang-orang bisa menjadi siapapun dan apapun. Artinya orang-orang akan mampu dalam membentuk realitas baru yang sebenarnya tidak berhubungan atau sama sekali tidak berhubungan dengan keadaan sebenarnya. Berkat interval postingan tersebut realitas yang tidak berkaitan tadi, diterima dan dianggap sebagai realitas yang sesungguhnya, mereka sudah melampaui realitas sebenarnya. Fakta ini kemudian hidup didalam memori kolektif dan menjadi sebuah cara pandang imajiner.

Iklan menawarkan berbagai kebutuhan-kebutuhan palsu dalam bingkai hiperealitas melalui simbol-simbol guna meningkatkan keinginan masyarakat untuk terus membeli (Hanif, 2011). Kesimpulannya Janji Jiwa punya kekuatan penuh untuk mempengaruhi persepsi masyarakat melalui media yang mereka bangun. Asumsinya, proses visualisasi membutuhkan narasi-narasi yang berada dalam media itu sendiri. Tindakan sosial sebagai sebuah bahasa mengendalikan makna pada tindakan dan praktik sosial (Setiawan, 2008). Terkait fenomena bahasa sebagai bagian pembentuk kebutuhan palsu dapat dibantu oleh pemikiran dari Michel Foucault, yaitu pengetahuan memberikan kuasa atau menambah relasi kuasa (Pratama, 2021). 


\section{Coffee shop Janji Jiwa Melampaui Realitasnya}

Wujud dari coffee shop Janji Jiwa memiliki wujud yang berbeda dari tempat lain sehingga memunculkan distingsi atau perbedaan dalam sebuah komoditas konsumsi. Pada hakikatnya coffee shop/ warung kopi memiliki nilai guna dan manfaat salah satunya sebagai ruang sosial. Saat ini coffee shop Janji Jiwa sebagai ruang sosial telah mengalami perubahan nilai substansinya. Proses komunikasi tatap muka yang terjadi di coffee shop/ warung kopi dahulunya lebih ditekankan, akan tetapi kini beralih menjadi gaya komunikasi bermedia. Terlihat dari aktivitas konsumsi para pengunjung coffee shop Janji Jiwa yang lebih menaruh perhatiannya pada gadget yang dimilikinya. Agar lebih mudah untuk dipahami penulis sudah merangkumnya ke dalam bentuk tabel, berikut hasil analisis penulis terkait Janji Jiwa melampaui realitasnya:

Tabel 3. Coffee shop Janji Jiwa dan hiperrealitas

\begin{tabular}{cccl}
\hline No & Penanda & $\begin{array}{c}\text { Coffee shop/ } \\
\text { Warung Kopi }\end{array}$ & \multicolumn{1}{c}{ Coffee shop Janji Jiwa } \\
\hline 1 & Konsumen & Universal & Kelas sosial dan Diferensiasi (Distingsi) \\
\hline 2 & Objek Material & Kopi & Harga dan Diferensiasi (Distingsi) \\
\hline 3 & Ruang & Ruang Publik & $\begin{array}{l}\text { Ruang Private } \\
\text { (Distingsi) }\end{array}$ \\
\hline 4 & Nilai Guna & $\begin{array}{l}\text { Manfaat Biologis } \\
\text { dan Ruang Sosial }\end{array}$ & $\begin{array}{l}\text { Fun System dan paksaan kenikmatan, } \\
\text { coffee shop sebagai proses signifikansi } \\
\text { dan klasifikasi (Distingsi) }\end{array}$ \\
\hline
\end{tabular}

Sumber: Disusun oleh penulis berdasarkan hasil penelitian dan analisis data

Jean P Baudrillard dalam bukunya menjelaskan simulasi dan hiperrealitas di dunia maya terjadi akibat dari kemajuan teknologi komunikasi sehingga mengaburkan batasan antara mana yang menjadi kenyataan dan mana yang menjadi kepalsuan (Aziz, 2001). Wujud dari Janji Jiwa telah melampaui kenyataannya sebagai salah satu kadai kopi. Tindakan konsumtif dalam kunjungan coffee shop Janji Jiwa bukan lagi berbicara tentang nilai guna, cita rasa, dan lainlain dari aktivitas tersebut, namun motif konsumsi yang bersifat konsumtif yang terjadi membentuk tindakan-tindakan kenikmatan dan kebahagiaan yang berbeda dengan secara fungsional dilihat dari kualitas, nilai guna, dan manfaat biologis.

\section{Simpulan}

Berdasarkan penelitian di atas maka penelitian ini dapat disimpulkan bahwa motif konsumsi pengunjung coffee shop Janji Jiwa pada dasarnya mencerminkan masyarakat konsumsi. Dimana konsumsi yang terjadi bukan didasari pada motif-motif pemenuhan kebutuhan biologis, melainkan sebagai bentuk pemenuhan kebutuhan afektif. Beberapa fakta yang terkumpul terkait motif konsumsi pengunjung coffee shop Janji Jiwa merupakan bukti irasionalitas masyarakat hari ini dalam realitas konsumsi. Mengenai konstruksi gaya hidup konsumerisme, faktanya banyak hal mempengaruhi terbentuknya perilaku konsumtif, jika mengacu pada perspektif Jean P Baudrillard maka ada empat poin penting yang berperan dalam membangun gaya hidup konsumerisme pengunjung coffee shop Janji Jiwa, yaitu: nilai tanda, logika sosial konsumsi, ruang sosial, dan media tontonan. Dari keseluruhan fakta tersebut kemudian membentuk yang namanya logika sosial konsumsi, logika-logika ini telah hidup dan menjadi sebuah pandangan imajiner dalam memori kolektif. Janji Jiwa dianggap sebagai sarana 
dalam proses signifikansi dan klasifikasi gaya hidup sejahtera melalui perlambangan kebahagiaan dan kelimpahruahan masyarakat post-industrialis.

Kemunculan masyarakat tontonan kemudian menjadikan masyarakat mengakui dan mengikuti adanya perbedaan-perbedaan tersebut. Meskipun ada faktor-faktor lain yang bisa menjadi penanda kelas sosial, akan tetapi orang-orang akan lebih mudah memahaminya kedalam bentuk wujud kasat mata. Dengan begitu munculah realitas simulasi baik yang abstrak menjadi konkrit atau sebaliknya yang konkret menjadi abstrak. Yang abstrak menjadi konkrit merupakan realitas dari kebutuhan palsu yang sengaja disimulasikan seolah-olah memang benar-benar menjadi kebutuhan. Sedangkan yang konkrit menjadi abstrak merupakan realitas dari simulasi yang diproduksi ulang, artinya melalui tindakan konsumsi dan perilaku konsumtif orang-orang mampu untuk membentuk status sosial mereka. Orang-orang mampu untuk menjadi siapapun dan apapun sehingga memunculkan hiperrealitas di mana orang-orang telah melampaui realitas dirinya, begitu pula dengan coffee shop Janji Jiwa, Janji Jiwa sudah melampaui nilai gunanya sebagai coffee shop, sehingga ada hal yang lebih penting ketimbang minumannya.

Keterbatasan dalam penelitian, memberikan peluang bagi peneliti-peneliti selanjutnya untuk mendalami topik yang sama, untuk itu peneliti selanjutnya diharapkan melanjutkan penelitian ini terkait topik-topik sosiologi ekonomi terutama dalam kajian fenomena budaya konsumerisme dalam berbagai tinjauan teoritis, karena pada dasarnya dalam kajian budaya konsumerisme kita tidak akan mampu menjelaskan secara menyeluruh tanpa adanya referensi lebih lanjut dari teoritis-teoritis lainya. Salah satu temuan kami yang dirasa perlu mendalami secara khusus yaitu terkait komodifikasi nilai nasionalisme dalam berbagai ornamen di coffee shop Janji Jiwa yang membentuk pandangan baru terhadap simulasi nilai-nilai nasionalisme baru.

\section{Daftar Pustaka}

Aziz, I. (2001). Galaksi Simulacra. Yogyakarta: LKiS.

Baudrillard, J. P. (2011). Masyarakat Konsumsi. Bantul: Kreasi Wacana.

Damsar, \& Indrayani. (2009). Pengantar Sosiologi Ekonomi. Jakarta: Prenadamedia Group.

Dewi, N. Y. (2013). One Dimension Man (Studi Terhadap Kritik Harbert Marcus Mengenai Masyarakat Modern). Universitas Islam Negeri Sultan Syarif Kasim Riau.

Dwiana, R. (2015). Peran Media Baru dalam Perubahan Relasi Kekuasaan. Pekommas, 18(3), 191-202.

Gultom, A. F. (2020). Konsumtivisme Masyarakat Satu Dimensi Dalam Optik Herbert Marcuse. Waskita: Jurnal Pendidikan Nilai Dan Pembangunan Karakter, 2(1), 17-30. https://doi.org/10.21776/UB.WASKITA.2018.002.01.2

Hanif, M. (2011). Studi Media dan Budaya Populer Dalam Perspektif Modernisme dan Postmodernisme. KOMUNIKA: Jurnal Dakwah Dan Komunikasi, 5(2), 235-251. https://doi.org/10.24090/KOMUNIKA.V5I2.174

Heryanto, A. (2015). Identitas dan Kenikmatan Politik Budaya Layar Indonesia. Jakarta: KPG (Kepustakaan Populer Gramedia).

Karman. (2014). Media Sosial: Antara Kebebasan Dan Eksploitasi Social Media : Between Freedom And Exploitation Karman. Jurnal Studi Komunikasi Dan Media, 18(1), 75-88.

Kheyene, M. B. (2013). Representasi Starbuck Coffee sebagai Gaya Hidup Konsumerisme: Monolog Kebudayaan Barat kepada Timur dalam Secangkir Kopi. Universitas Diponegoro.

Laksmi, D. (2020). Rajin Ngopi, Belum Rajin Genjot Produksi. https://interaktif.kompas.id/ baca/rajin-ngopi/

Jurnal Socius: Journal of Sociology Research and Education Vol. 8, No. 2, Th. 2021 
M. Abdi Azzarra, Azwar Azwar, Elfitra Elfitra Masyarakat Konsumsi dan Simulasi Pengunjung Coffee Shop Janji Jiwa di Kota Padang

Lestari, A. A. (2020). Analisis Perbandingan Brand Equity Kopi Janji Jiwa dan Kopi Kenangan. Universitas Trilogi.

Lubis, A. S. A. (2020). Kajian Tentang Masyarakat Konsumtif dengan Perspektif Jean P Baudrilard (Interpretasi Simulasi Konsumen Starbuck Coffee di Kota Medan. Universitas Sumatera Utara.

Piliang, Y. A. (2011). Sebuah Dunia yang Dilipat. Bandung: Pustaka Matahari.

Pratama, R. A. (2021). Kekuasaan, Pengetahuan, dan Hegemoni Bahasa dalam Perspektif Michele Foucaoult dan Francis Bacon. Jurnal Filsafat Indonesia, 4(1), 33-43.

Ritzer, G. (2014). McDonaldisasi Masyarakat. Yogyakarta: Pustaka Pelajar.

Salendra, S. (2014). Coffee Shop As a Media for Self-Actualization Today's Youth. Jurnal The Messenger, 6(2), 49-57. https://doi.org/10.26623/THEMESSENGER.V6I2.192

Sembiring, N. T. B. (2020). Gaya hidup Milenial: Studi Kasus Pengunjung Cafe Live Musik Holywing di Kota Medan. Universitas Sumatera Utara.

Stellarosa, Y. (2020). Kecanduan Belanja. Sukasari: Indigo Media.

Strinati, D. (2021). Populer Culture Pengantar Menuju Teori Budaya Populer. Jakarta: RRauzz Media.

Susilo, F. (2015). Fragmentasi Manusia dalam Kultur Makan Masa Kini. MELINTAS. https://doi.org/10.26593/mel.v31i2.1625.201-219

Teguh, C., Fkip, D., Sanata, U., Yogyakarta, D., Affandi, J., \& Mrican, G. (2010). Pengaruh Media Massa dan Pengetahuan Tentang Teknologi Informasi Terhadap Pemanfaatan Teknologi Informasi dan Tingkat Modernitas Generasi Muda Kota Yogyakarta. Jurnal Ilmu Komunikasi, 8(1), 1-8.

Willy, \& Nurjanah, S. (2019). Pengaruh Kemasan Produk terhadap Minat beli. Jurnal Ilmu Managemen, 9(9), 20-32.

Yandri, S. (2017). Pengalaman Empiris menjadi Sebuah Ide dalam Penciptaan Musik. Dewaruci, 12(1), 31-39.

Yayuk, W. (2019, September). Kian Banyak Orang Indonesia Minum Kopi, Berapa Jumlah yang Ideal? - Gaya Tempo.co. 